\title{
Alterations in alanine metabolism in diabetic dogs during short-term treatment with an artificial B cell
}

\author{
E.-J. Freyse, U. Fischer, G. Albrecht and E. Salzsieder \\ Central Institute of Diabetes “Gerhardt Katsch”, Karlsburg, GDR
}

\begin{abstract}
Summary. The flux rates of plasma glucose and alanine were studied isotopically $\left(6-{ }^{3} \mathrm{H}\right.$-glucose and $\mathrm{U}_{-}^{14} \mathrm{C}$-alanine simultaneously) in resting chronically diabetic dogs during shortterm treatment with an artificial B cell where the insulin was infused into a peripheral vein. Despite perfect blood glucose control and normal glucose flux rates, the concentration and rates of appearance and disappearance of alanine were significantly elevated in the diabetic animals before, during and after an exogenous glucose load. The incorporation of the carbon moiety of alanine into circulating glucose was also increased, but diminished to a near-normal extent when exoge-
\end{abstract}

nous glucose was given. The plasma clearance rates for alanine in the diabetic dogs were normal throughout the study. It is concluded that normal blood glucose control in diabetes does not necessarily mean normalization of the entire metabolic network. On the basis of peripheral hyperinsulinaemia alanine formation from glucose and branched chain amino acids is elevated in muscle. This may explain increased flux of alanine despite normal blood glucose control.

Key words: Artificial B cell, dog, experimental diabetes, alanine metabolism, gluconeogenesis, tracer study,
Artificial B cell-mediated blood glucose control provides normal glucose flux rates both under basal conditions and after a glucose load in diabetes [1,2]. If, however, during short-term application, insulin is administered via the peripheral route, several other metabolic parameters remain pathological. Thus, circulating glucose precursor concentrations are usually elevated [3-6]. In an apparent contrast to these findings, rates of glucose carbon re-circulation were found to be diminished under these conditions both in diabetic patients [6] and dogs [1].

The present study deals with alanine metabolism in chronically diabetic dogs during normal glucose regulation by means of feedback-controlled peripheral venous insulin administration. Endogenous alanine is produced in skeletal muscle on the basis of carbon moieties from glucose and amino acids and of the amino groups resulting from protein catabolism; alanine serves predominantly as a substrate for hepatic gluconeogenesis (glucose-alanine cycle: 7). In untreated diabetes, decreased plasma alanine concentrations have been observed in combination with both a reduced production rate [8] and increased gluconeogenesis [8-12]. The longterm use of a peripheral venous insulin pump, however, leads to elevated plasma alanine concentrations [3]. In a preliminary study of insulin-treated diabetic dogs, we observed hyperalaninaemia even if insulin therapy was not optimal; an intravenous bolus injection of a blood glucose lowering insulin dose did not affect the plasma alanine values in these animals or in healthy controls (unpublished data). Therefore the question arises whether the flux rates of alanine are altered under the influence of insulin and glucose in diabetes.

Since there is an apparent relation between concentrations and metabolic rates of alanine in vivo $[8,13]$, it was the aim of this study to investigate the effect of perfect blood glucose control on simultaneously measured flux rates of glucose $\left(6-{ }^{3} \mathrm{H}\right.$-glucose) and alanine $\left(\mathrm{U}_{-}{ }^{14} \mathrm{C}\right.$ alanine) under basal conditions and during an intravenous glucose load.

\section{Materials and methods}

\author{
Animals \\ Six non-diabetic (mean \pm SEM, weight: $28 \pm 2 \mathrm{~kg}$, age: $31 \pm 5$ months) \\ and five diabetic Alsatian dogs of both sexes $(34 \pm 2 \mathrm{~kg}, 44 \pm$ \\ 5 months; duration of diabetes $10 \pm 2$ months, insulin requirement in \\ daily therapy employing three subcutaneous injections of regular por- \\ cine monocomponent insulin $1.55 \pm 0.06 \mathrm{IU} / \mathrm{kg}$ Actrapid MC, Novo, \\ Copenhagen, Denmark) were studied. One of the diabetic animals \\ was investigated in the control group before it was rendered diabetic.
}


Diabetes was produced by subtotal pancreatectomy with intrasurgical infusion of a small dose of streptozotocin [14]. The animals were canine C-peptide-negative and had no anti-insulin antibodies. Their long-term metabolic situation was characterized by an average glycaemia over the day of $10.4 \pm 0.8$ and a maximum amplitude of glycaemic excursions of $19.6 \pm 2.2 \mathrm{mmol} / 1$ as taken from seven estimates around the clock (control animals: $5.2 \pm 0.1$ and $1.0 \pm 0.1 \mathrm{mmol} / 1 \mathrm{re}-$ spectively).

\section{Experimental design}

The turnover rates of glucose and of alanine were estimated isotopically before, during and after an exogenous load of unlabelled glucose in the non-medicated animals [1]. During these tests the diabetic animals were treated intravenously with glucose-controlled insulin infusions (GCII) to restore fasting normoglycaemia and to keep the glycaemic responses as close to normal as possible [15].

Immediately before the experiments ( $14 \mathrm{~h}$ after the last meal and in the case of the diabetic dogs - the last subcutaneous insulin injection), the animals were prepared with three indwelling catheters without anaesthesia, one in the jugular vein (Cavafix RMT, Braun, Melsungen, FRG) for blood sampling from the upper caval vein; one in the cephalic vein for glucose monitoring during GCII (Polyethylene Cannula, VEB Kombinat MLW, Medizinplaste Lichtenberg, GDR); and another in the pelvic lower caval vein via a saphenous vein (Teflon Portex Intravenous Tubing, Hythe, Kent, UK) to administer infusions. These consisted of a constant background infusion of saline $(0.154 \mathrm{mmol} / \mathrm{l}, 0.5 \mathrm{ml} / \mathrm{min})$ which was supplemented with a solution of tracer $(0.1 \mathrm{ml} / \mathrm{min})$, unlabelled glucose according to protocol $(1.0 \mathrm{ml} / \mathrm{min})$, and - during the GCII - insulin $\left(0.1 \mathrm{ml} \cdot \mathrm{kg}^{-1} \cdot \mathrm{min}^{-1}\right.$, pulses of variable duration according to glycaemia).

At $05.00 \mathrm{~h}$ on the day of the experiment, the diabetic animals were injected intravenously with an individually adapted dose of the insulin formulation as described above (average 9.0 $\pm 1.2 \mathrm{IU} /$ animal). From $07.00 \mathrm{~h}$, the GCII were applied throughout the experiment: the average total insulin requirement over $10 \mathrm{~h}$ was $16.3 \pm 2.7 \mathrm{IU} /$ animal, basal dose $0.51 \pm 0.10 \mathrm{mU} \cdot \mathrm{kg}^{-1} \cdot \mathrm{min}^{-1}$, dose during exogenous glucose load $0.32 \pm 0.12 \mathrm{IU} / \mathrm{kg}$ within $2 \mathrm{~h}$.

The specific activities of circulating substrates were analyzed at intervals of $15 \mathrm{~min}$ from $90 \mathrm{~min}$ after the beginning of tracer infusion. The intravenous load of unlabelled glucose was given from 210 to $330 \mathrm{~min}$ after the beginning of tracer infusion. During the experiments, the hematocrit declined to the same extent in the diabetic animals (beginning: $0.45 \pm 0.01$, end: $0.42 \pm 0.02$ ) as in the controls $(0.44 \pm 0.01$ and $0.40 \pm 0.01$ respectively)

\section{Infusates}

L-U- ${ }^{14} \mathrm{C}$-alanine $(7.4 \mathrm{mBq}$, sp. act. $6.327 \mathrm{GBq} / \mathrm{mmol})$ and $37.0 \mathrm{MBq}$ D-6- ${ }^{3} \mathrm{H}$-glucose (sp. act. $1.369 \mathrm{GBq} / \mathrm{mmol}$ ), both from Amersham International (Amersham, Bucks, UK), were purified by ion exchange chromatography the day before the experiment and made up with saline $(0.154 \mathrm{mmol} / \mathrm{l})$ to $50.0 \mathrm{ml}$ under sterile conditions. Ten percent of this total dose was applied as an initial bolus injection; the remainder was infused continuously during the experiment. The calculated constant dose was $14.8 \mathrm{KBq} / \mathrm{min}$ for ${ }^{14} \mathrm{C}$-alanine and $74 \mathrm{KBq} / \mathrm{min}$ for ${ }^{3} \mathrm{H}$ glucose; the applied dose was analyzed in each experiment [1]. Unlabelled glucose was dissolved in water to allow the same dose $\left(56.67 \mu \mathrm{mol} \cdot \mathrm{kg}^{-1} \cdot \mathrm{min}^{-1}\right)$ and the same infusion rate in each experiment (average concentration $337 \mathrm{mg} / \mathrm{ml}$ ). Insulin (same formulation as above) was diluted with saline $(0.154 \mathrm{mmol} / 1)$ and $10 \%$ sterile homologous serum $(\mathrm{v} / \mathrm{v})$ to give a concentration of $240 \mathrm{mU} / \mathrm{ml}$.

\section{Chemical analyses}

Sampling and storage of specimens and the determination of ${ }^{3} \mathrm{H}$-glucose specific activity have been described elsewhere [1]. Plasma glucose for glucose monitoring was determined by a glucose oxidase/
$\mathrm{PO}_{2}$ technique (Beckman analyzer, Fullerton, California, USA); immunoreactive insulin activity was analyzed according to a back titration/alcohol precipitation principle [16], and immunoreactive glucagon was estimated by a double antibody technique [17]. The guinea pig anti-glucagon antiserum No.43 (Zentralinstitut für Diabetes "Gerhardt Katsch", Karlsburg, GDR) and the WHO pancreatic glucagon calibration standard No.69/194 were used for this assay which exhibited a $5 \%$ cross-reactivity with porcine entero-glucagon-like immunoreactivity. The concentrations of glucose [18], lactate [19], $\beta$ hydroxybutyrate [20] and alanine [21] were measured spectrophotometrically (Photometer Eppendorf $1101 \mathrm{M}$, Netheler + Hinz GmbH, Hamburg, FRG) from $2 \mathrm{ml}$ of plasma. After deproteination $(2 \mathrm{ml}$ $\left.0.5 \mathrm{~mol} / 1 \mathrm{HClO}_{4}\right)$, alanine was separated from the extract by chromatography on a 5 -ml column (Quick-Sep, Panchem, Kleinwallstadt, FRG) by a cation exchange resin (Dowex $50 \mathrm{WX} 8,200-400$ mesh, Serva, Heidelberg, FRG) and was re-eluted with $1.78 \mathrm{~mol} / \mathrm{l}$ ammonia [22]. Since no appreciable carbon incorporation into other amino acids has been reported under comparable conditions [23], no attempt was made to separate them from this fraction. To obtain glucose and lactate specific activities, the chromatographed acid extracts were neutralized $\left(5 \mathrm{~mol} / 1 \mathrm{~K}_{2} \mathrm{CO}_{3}\right)$ and re-chromatographed (anion exchange resin Dowex 1X8, 200-400 mesh, Serva) [24].

For liquid scintillation counting, all chromatographed samples were lyophylized and dissolved in distilled water. All scintillation counting was performed over 5 or $10 \mathrm{~min}$ in Bray's solution [25] on a liquid scintillation spectrometer (Tricarb, Model 2650, Packard, Vienna, Austria).

\section{Data analysis}

Recovery of the analytical substrates after this procedure was $92 \pm 1 \%$ (glucose, $n=25$ ), $75 \pm 2 \%$ (lactate, $n=28$ ), and $86 \pm 3 \%$ (alanine, $n=23$ ). On the basis of previous reports $[26,27]$ Steele's one-compartment model as adapted to non-steady state conditions [28] was employed to calculate the turnover rates of glucose and alanine. On the basis of our own unpublished data, the apparent distribution spaces employed in all computations were $200 \mathrm{ml} / \mathrm{kg}$ for glucose and $176 \mathrm{ml} / \mathrm{kg}$ for alanine with no difference between normal dogs and normoglycaemic diabetic dogs. The formation of glucose from the alanine carbon moiety was calculated [29] as

$$
\text { percentage glucose from alanine }=\frac{\mathrm{sp} . \text { act. }{ }^{14} \mathrm{C} \text { glucose }}{\mathrm{sp} \text {. act. }{ }^{14} \mathrm{C} \text { alanine }} \times 0.5 \times 100
$$

where the factor 0.5 results from the two alanine molecules that are theoretically necessary to yield one glucose molecule. These calculations were not performed for the intervals when unlabelled exogenous glucose was applied, because the specific activities of ${ }^{14} \mathrm{C}$ in circulating glucose is artificially diluted by the test load. To compensate for under-estimation of glucose formation from alanine due to random metabolic exchange of carbon atoms in the hepatic oxaloacetate pool, the glucose formation data were multiplied by 2.2 , as established by Hetenyi [30]. The results are expressed as mean \pm SEM, and Student's $\mathrm{t}$-test for non-paired data $(p<0.05)$ was used where appropriate.

\section{Results}

\section{Glucose metabolism}

The diabetic animals had an initial plasma glucose concentration of $22.3 \pm 3.8 \mathrm{mmol} / \mathrm{l}$ which was restored to normal within $3 \mathrm{~h}$ after the beginning of intravenous insulin administration in the morning (data not shown). There was essentially no difference between the two groups during the steady state before initiation of glucose infusion in glycaemia (diabetic dogs $5.22 \pm 0.18$, controls $5.67 \pm 0.21 \mathrm{mmol} / \mathrm{l}$ ) or in glucose flux rates 


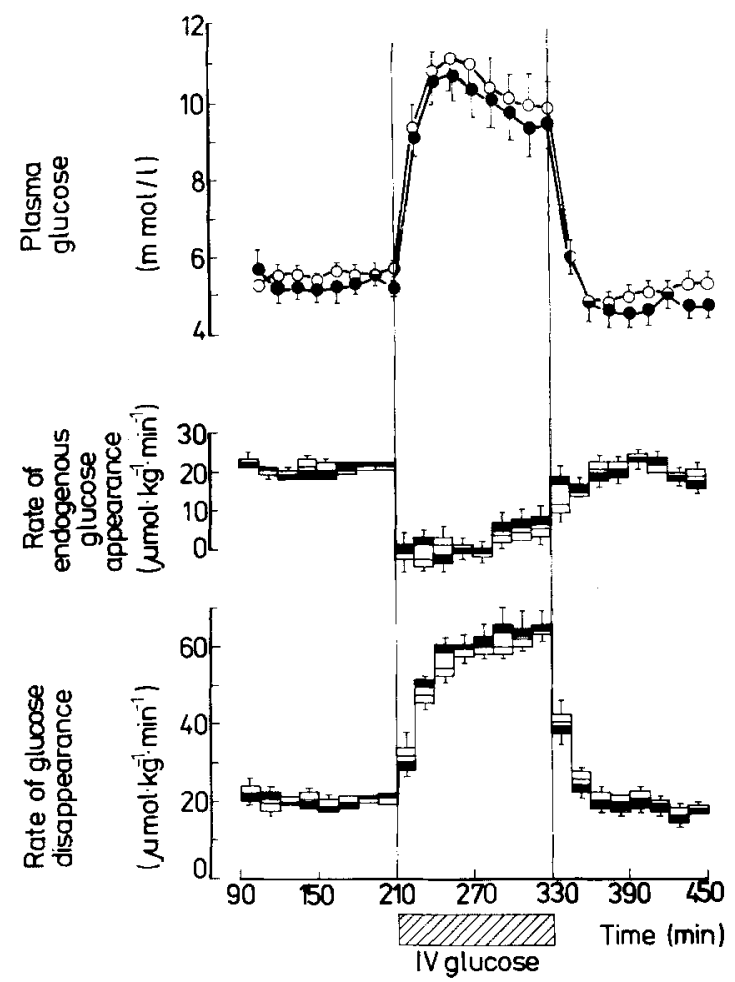

Fig. 1. Concentrations and flux rates of plasma glucose as estimated from $6{ }^{3} \mathrm{H}$-glucose specific activities in normal $(n=6,0-0$, $\square \square)$ and diabetic dogs on the artificial B cell $(n=5$,

- before, during and after an intravenous glucose infusion test $\left(56.67 \mu \mathrm{mol} \cdot \mathrm{kg}^{-1} \cdot \mathrm{min}^{-1}, \nabla\right)$. To show the endogenous appearance rate during the infusion of unlabelled glucose, the dose infused was subtracted from the estimated total glucose appearance rate. "0 min" would denote the beginning of the primed isotopic tracer infusion. In the diabetic dogs, controlled intravenous insulin supply was initiated 2 hours before the tracer infusion

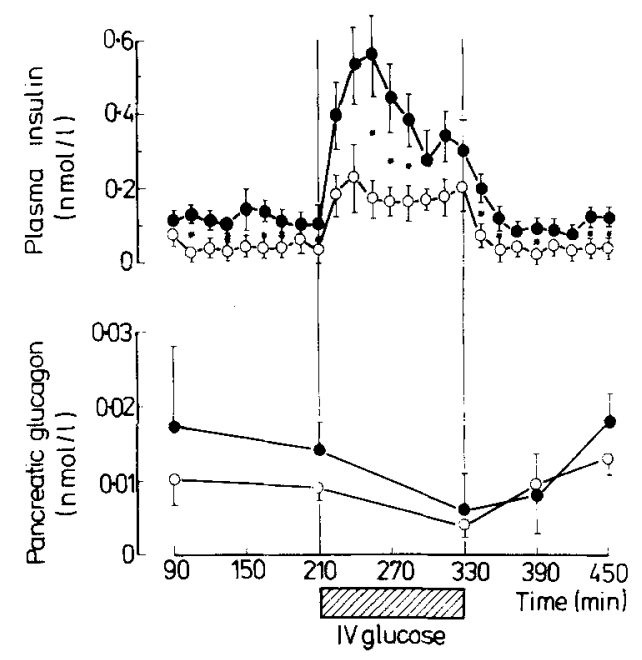

Fig. 2. Mixed venous plasma insulin and pancreatic glucagon concentrations in normal $(n=6,0-0)$ and diabetic dogs on the artificial B cell $(n=5,-)$ in the same tests as given in Figure 1. Significant differences between the groups

(diabetic dogs $20.59 \pm 2.40$, controls $20.44 \pm 1.16 \mu \mathrm{mol}$. $\left.\mathrm{kg}^{-1} \cdot \min ^{-1}\right)$. This held true during the entire period when alanine metabolism was studied (Fig.1). Furthermore, in the diabetic animals the endogenous glucose production was suppressed to a normal extent when the intravenous load of exogenous glucose was applied (Fig.1). Moreover, the peripheral $\beta$-hydroxybutyrate levels were near-normal throughout the experiment (diabetic dogs before the glucose infusion test: $0.060 \pm$ $0.022 \mathrm{mmol} / \mathrm{l}$, normal dogs: $0.020 \pm 0.003 \mathrm{mmol} / \mathrm{l}$, difference not significant). However, the circulating lactate concentrations remained at a higher level in the diabetic dogs: before glucose infusion it was $0.42 \pm 0.07 \mathrm{mmol} / 1$ in relation to $0.23 \pm 0.06 \mathrm{mmol} / 1$ in the controls $(p<$ 0.05 ).

The peripheral plasma pancreatic glucagon levels and their responses to glucose administration were also near-normal throughout the experiment (Fig. 2). There was, however, a distinct hyperinsulinaemia in the mixed venous blood during the entire period in the diabetic animals (Fig. 2). The basal levels were 3 times higher (diabetic dogs: $0.10 \pm 0.03 \mathrm{nmol} / 1$, controls $0.03 \pm$ $0.01 \mathrm{nmol} / 1, p<0.05$ ). There was roughly the same relation during the glucose infusion test and the interval thereafter.

\section{Basal alanine metabolism}

The plasma alanine concentrations in mixed venous blood was significantly elevated in the diabetic dogs: e. g. immediately before the glucose test $0.32 \pm 0.05$ in relation to $0.18 \pm 0.02 \mathrm{mmol} / 1$ in the controls. Accordingly, these animals exhibited higher rates of alanine appearance in the circulation: $8.52 \pm 0.89$ and $5.11 \pm$ $0.63 \mu \mathrm{mol} \cdot \mathrm{kg}^{-1} \cdot \mathrm{min}^{-1}$ respectively at the same time during the experiment $(p<0.05$, Fig. 3$)$. Since the plasma concentration did not change in both groups, these data also represent the alanine disappearance (i. e. hepatic utilization) and therefore show the total alanine turnover. No difference was evident in the apparent metabolic clearance rates (Fig. 3). However, in the diabetic animals under these conditions a significantly elevated amount of glucose carbon atoms originated from alanine: $15.6 \pm 3.0$ vs. $6.8 \pm 0.8 \%$ of the rate of appearance of glucose. (Fig. 3).

The ${ }^{14} \mathrm{C}$-activities in the lactate-containing plasma fractions were usually smaller than 30 DPM in a given sample (see Methods), i. e. the specific activities could not be determined with sufficient accuracy because they could not be differentiated from background $-{ }^{14} \mathrm{C}$-activity.

\section{Alanine metabolism during the intravenous glucose load}

There was no significant change in the plasma alanine concentrations (Fig. 3) which continued to show higher levels in the diabetic dogs. The flux rates, however, responded to hyperglycaemia and hyperinsulinaemia with a reversible increase. In the diabetics, the maximal observed alanine turnover amounted to $13.14 \pm$ $3.06 \mu \mathrm{mol} \cdot \mathrm{kg}^{-1} \cdot \mathrm{min}^{-1}$, i. e. an average increase of $70 \%$ at the end of the glucose load. In the controls the related 


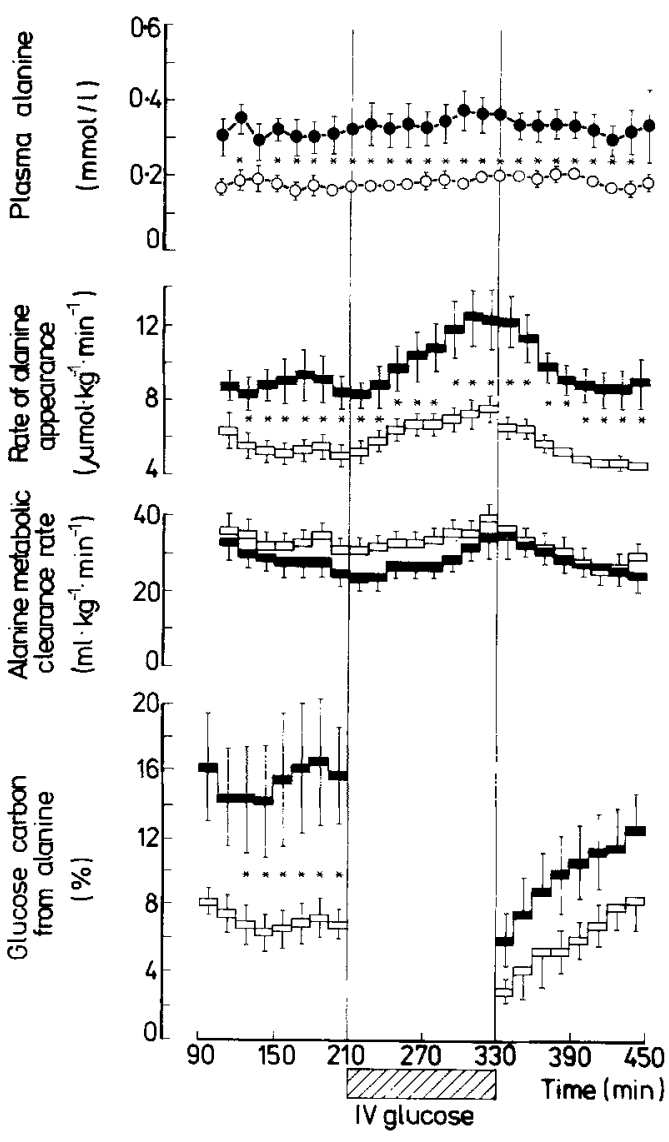

Fig.3. Alanine metabolic patterns in normal $(n=6, \bigcirc-O, \square-\square)$ and diabetic dogs on the artificial B cell $(n=5,-\infty, \square)$ in the same tests as given in Fig. 1. Panels from top:- plasma alanine concentration; - alanine flux rates as estimated from the specific activities of plasma-U $-{ }^{14} \mathrm{C}$-alanine (since the plasma concentration was in steady state, the rates of appearance and of disappearance are virtually identical); - metabolic clearance rates of alanine from mixed venous plasma; - relative share of alanine flux rate in glucose appearance, i. e. apparently in hepatic gluconeogenesis. This estimate was not obtained for the interval when non-labelled glucose was infused, because the specific ${ }^{14} \mathrm{C}$-activity to circulating glucose did not exclusively represent endogenous dilution of the label. Significant differences between the groups

numbers were $7.69 \pm 0.74 \mu \mathrm{mol} \cdot \mathrm{kg}^{-1} \cdot \mathrm{min}^{-1}$ and $50 \%$ respectively. The relative increase in alanine flux was not significantly different between the two groups.

Since this increase in alanine turnover was not paralleled by a change in plasma alanine concentration, the apparent metabolic clearance rates of plasma alanine were also found to rise (Fig. 3). This was significant in the control animals: $31.3 \pm 2.9$ vs. $40.1 \pm 3.0 \mathrm{ml} \cdot \mathrm{kg}^{-1}$. $\mathrm{min}^{-1}$ at the end. It should, however, be noted that, in general, there was no difference in the metabolic clearance rates of alanine between the two groups of animals.

Although the exogenous glucose load did suppress the endogenous glucose appearance to negligible rates (Fig. 1) and no rates of glucose formation from alanine carbon could be calculated, there was still a significant shift of the carbon label from the alanine pool to circulating glucose. This could be reproduced in all animals of both groups during the entire period of external glucose supply. Thus, precise rates of alanine conversion to glucose were again observed from the beginning of the post-glucose infusion period (Fig.3).

\section{Discussion}

On the basis of a total lack of endogenous $\beta$-cell function, the animals investigated in this study were chronically diabetic. Their long-term treatment, employing three subcutaneous injections of short-acting insulin, was generally insufficient. This is particularly obvious when the second half of the night is considered: glycaemia was always $>20 \mathrm{mmol} / \mathrm{l}$ but peripheral insulinaemia was not measurably low. In contrast to some other reports [11, 23], the plasma alanine levels were also elevated in this situation.

In the diabetic animals the feedback-controlled intravenous insulin administration did restore to normal both glycaemia and endogenous glucose flux rates for a relatively short interval under basal conditions and during parenteral glucose administration. However, to reach these perfect "blood glucose cosmetics", hyperinsulinaemia was induced in the posthepatic circulation as described before $[2,31]$. Since this peripheral plasma insulin elevation was about threefold in relation to the control animals, it may be speculated that normal amounts of insulin were available in the liver (hepatic extraction approximately $50 \%)(32,33)$ but without restoration of the normal portal-peripheral gradient of insulin concentration. Also, the circulating glucagon concentrations were in the near-normal range during the tests. Thus the insulin: glucagon ratio in the liver, which appears most important in control of hepatic glucose production [34], is assumed to be normal.

The data reported here on alanine metabolism correspond closely to those obtained by other authors who found plasma concentrations around $0.2 \mathrm{mmol} / 1$ [35-37], production rates between 5 and $7 \mu \mathrm{mol} \cdot \mathrm{kg}^{-1}$. $\min ^{-1}[8,22,35,38]$ and a relative share of glucose carbon from alanine metabolism around $6 \%[26,38]$. The increase in alanine flux during comparable glucose loads was about $50 \%$ during comparable glucose loads in healthy men [35].

In the experimental animals of this study, the alanine-glucose cycle was working under the condition of a chronic diabetes in normoglycaemic, resting, shortterm fasting subjects that were well nourished, especially without any protein-malnutrition that could have influenced the balance of proteins and amino acids in muscle.

Both under basal conditions and during parenteral glucose administration in these animals, there were elevated circulating concentrations and flux rates of alanine with a normal response to the exogenous glucose load. Since similar increases in alanine concentration have been shown in diabetic dogs during long-term in- 
sulin infusion [3], it appears improbable that these alterations are simply due to an only short-term optimal glycaemic control.

Despite the reported amount of up to about $20 \%$ of alanine released from skeletal muscle which have received their carbon moieties from products of glycolysis [7], the fluxes of alanine and of glucose in muscle appear as independent processes in vitro $[39,40]$ and - according to findings in literature - the production of alanine in man is only negligibly influenced by variations in the metabolic rate of glucose [35, 37, 41]. In our preliminary study (see above), an insulin-induced blood glucose decrease in normal and in diabetic dogs with identical plasma insulin patterns did not influence the circulating plasma alanine concentration. Since in this investigation there were also identical metabolic patterns of glucose in both groups, it is concluded that the peculiarities in alanine flux are not caused by simple quantitative differences in glucose metabolism. Employing mathematical modelling of metabolic processes, it has been shown by Albisser et al. [42] that, in contrast to the physiological action of insulin, the hormone is mainly acting in the extrahepatic tissues when applied intravenously. In the light of these findings, the peripheral hyperinsulinaemia observed here in the diabetic animals might have caused higher amounts of amino acids [7], especially of branched-chain species, to provide amino groups and carbon moieties for alanine synthesis in muscle $[39,40,43]$.

In the range observed, there is obviously no limitation of hepatic alanine uptake $[7,35]$. This is also confirmed by the increase in metabolic clearance rates of alanine as shown in this study. Therefore it is concluded that the differences observed in circulating alanine concentrations between the diabetic and the control animals are not based on an insufficient utilization of alanine in gluconeogenesis. Despite a clear-cut suppression in hepatic glucose output during the glucose load, there is still an appearance of alanine-derived carbon atoms in the circulating glucose pool which could unfortunately not be quantified in this study [44].

In addition it might be speculated that the flux of alanine carbon is directed into other metabolic compartments, e.g. into glycogen $[35,45]$. This might also explain the reduced rate of carbon recirculation (Cori cycle) which was found under these conditions in diabetic patients [6] and dogs [1] despite high circulating levels of alanine and lactate.

Possible consequences of these phenomena on protein and amino-acid metabolism during artificial B cell treatment remain to be investigated. Also whether perfect blood glucose control for a longer interval or sufficient hepatic and peripheral insulin supply could restore complete physiological metabolic patterns need to be studied.

Acknowledgements. This study was part of the research project HFR 22/2.2.02 of the Ministry of Health of the German Democratic Republic. Skillful technical assistance from Ms. H.Buff, Ms.
H.Schröder, Ms. K. Brüllke and Ms. K. Köhler is gratefully acknowledged. The radioimmunoassays were supervised by Dr. W. Besch.

\section{References}

1. Freyse EJ, Fischer U, Albrecht G (1983) Glucose metabolism studied isotopically in diabetic dogs: effect of restoration of peripheral normoinsulinaemia by the artificial $\beta$ cell. Diabetologia 25: 411-417

2. Zinman B, Stokes EF, Albisser AM, Hanna AK, Minuk HL, Stein AN, Leibel BS, Marliss EB (1979) The metabolic response to glycemic control by the artificial pancreas in diabetic man. Metabolism 28: 511-51?

3. Albisser AM, Goriya Y, Bahoric A, Marliss EB, Zinman B (1979) Persistent hormonal and metabolic abnormalities inspite of glucose normalization: long term studies with peripheral open-loop insulin delivery in diabetic dogs. In: Waldhäusl WK (ed) Diabetes 1979. Proceedings 10th International Diabetes Federation Meeting, Vienna 1979. Excerpta Medica, Amsterdam Oxford Princeton, pp 644-648

4. Hanna AK, Zinman B, Nakhooda AF, Minuk HL, Stokes EF, Albisser AM, Leibel BS, Marliss EB (1980) Insulin, glucagon, and amino acids during glycemic control by the artificial pancreas in diabetic man. Metabolism 29:321-332

5. Nattrass M, Alberti KGMM, Buckle ALJ, Cluett B, Jaspan JB, Noy GA, Stubbs WA, Walton R (1979) Metabolic studies during normoglycaemic clamping of insulin-dependent diabetics using a glucose-controlled insulin infusion system. Horm Metab Res Suppl ser 8: 86-92

6. Nosadini R, Noy GA, Nattrass M, Alberti KGMM, Johnston DG, Home PD, Ørskov $H$ (1982) The metabolic and hormonal response to acute normoglycaemia in Type I (insulin-dependent) diabetes: studies with a glucose controlled insulin infusion system (artificial endocrine pancreas) Diabetologia 23: 220-228

7. Felig P (1973) The glucose-alanine cycle. Metabolism 22: 179-207

8. Hall SEH, Braaten JT, McKendry JBR, Bolton T, Foster D, Berman $M$ (1979) Normal alanine-glucose relationships and their changes in diabetic patients before and after insulin treatment. Diabetes 28: 737-745

9. Cherrington AD, Lacy WW, Chiasson JL (1978) Effect of glucagon on glucose production during insulin deficiency in the dog. $J$ Clin Invest 62: 664-677

10. Hetenyi jr G, Pagurek B, Dittmar EA, Ferrarotto C (1980) The effects of methylprednisolone and diabetes on the turnover of alanine and on the transfer of carbon atoms from alanine to pyruvate and glucose in dogs. Canad $\mathbf{J}$ Physiol Pharmacol 58: 787-796

11. Elia M, Ilic V, Bacon S, Williamson DH, Smith R (1980) Relationship between the basal blood alanine concentration and the removal of an alanine load in various clinical states in man. Clin Science 58: 301-309

12. Hetenyi G, Layberry RA, Foster DM, Berman M (1980) Transfer of carbon atoms among circulating glucose, alanine and lactate in pancreatectomized dogs. Am J Physiol 239: E39-E44

13. Waterhouse C, Keilson $\mathbf{J}$ (1978) The contribution of glucose to alanine metabolism in man. $J$ Lab Clin Med 92: 803-812

14. Freyse EJ, Hahn von Dorsche H, Fischer U (1983) Low dose streptozotocin diabetes after partial pancreatectomy in dogs. Histological findings in a new type of experimental diabetes. Acta Biol Med Germ 41: 1203-1210

15. Fischer U, Jutzi E, Bombor H, Freyse EJ, Salzsieder E, Albrecht $G$, Besch W, Bruns W (1980) Assessment of an algorithm for the artificial $\beta$ cell using the normal insulin-glucose relationship in diabetic dogs and man. Diabetologia 18:97-107

16. Gottschling DM, Ziegler M, Wilke W, Michael R (1974) Radioimmunoassay von Plasmainsulin - methodenkritische Untersuchungen. Radiobiol Radiother 15:91-97

17. Ziegler M, Wilke W, Kohnert KD, Klatt D (1975) Spezifischer Radioimmunoassay für Pankreasglukagon im Blut. In: Bibergeil $\mathrm{H}$, Fiedler H, Poser U (eds) Frühdiabetes: Pathogenese, Diagnose, 
Prävention. Proceedings of the 8th Symposium, Central Institute of Diabetes "Gerhardt Katsch", Karlsburg, GDR, 1974, pp $413-416$

18. Bergmeyer HU, Bernt E, Schmidt F, Stork H (1970) Chapter D. In: Bergmeyer HU (ed) Methoden der enzymatischen Analyse. Akademie-Verlag, Berlin, pp 1163-1165

19. Hohorst HJ (1970) Chapter D. In: Bergmeyer HU (ed) Methoden der enzymatischen Analyse. Akademie-Verlag, Berlin, pp 1425-1429

20. Williamson DH, Mellanby J (1970) Chapter D. In: Bergmeyer HU (ed) Methoden der enzymatischen Analyse. Akademie-Verlag, Berlin, pp 1772-1776

21. Williamson DH (1970) Chapter D. In: Bergmeyer HU (ed) Methoden der enzymatischen Analyse. Akademie-Verlag, Berlin, pp 1634-1636

22. Sauerwein HP, Michels RPJ, Cejka V (1981) Alanine turnover in the postabsorptive state and during parenteral hyperalimentation before and after surgery. Metabolism 30: 700-705

23. Chochinov RH, Perlman K, Moorhouse JA (1978) Circulating alanine production and disposal in healthy subjects. Diabetes 27 : 287-295

24. Hofer HW (1974) Separation of glycolytic metabolites by column chromatography. Anal Biochem 61: 54-61

25. Bray GA (1960) A simple efficient liquid scintillator for counting aqueous solutions in a liquid scintillation counter. Anal Biochem $1: 279-285$

26. Bier DM, Arnold KJ, Sherman WR, Holland WH, Holmes WF, Kipnis DM (1977) In vivo measurements of glucose and alanine metabolism with stable isotopic tracers. Diabetes 26:1005-1015

27. Prior RL, Christenson RK (1977) Gluconeogenesis from alanine in vivo by the ovine fetus and lamb. Am J Physiol 233: E462-E468

28. Steele R (1959) Influence of glucose loading and of injected insulin on hepatic glucose output. Ann NY Acad Sci 82: 420-430

29. Forbath N, Hetenyi jr G (1969) Metabolic interrelations of glucose and lactate in unanesthetized normal and diabetic dogs. Can J Physiol Pharmacol 48: 115-122

30. Hetenyi jr $\mathrm{G}$ (1982) Correction for the metabolic exchange of ${ }^{14} \mathrm{C}$ for ${ }^{12} \mathrm{C}$ atoms in the pathway of gluconeogenesis in vivo. Fed Proc 41: 104-109

31. Horwitz DL (1979) Insulin responses to mixed meals: comparison of an artificial beta cell and normal beta cells. Horm Metab Res [Suppl] 8: 68-71

32. Field JB, Harding P, Kaden M (1973) Effect of intraduodenal glucose administration on hepatic insulin extraction in the anesthetized dog. VIII Congress of the International Diabetes Federation. Excerpta Med Int Congr Ser 280: 15-16 (Abstract)

33. Kaplan N, Madison LL (1959) Effects of endogenous insulin secretion on the magnitude of hepatic binding of labeled insulin during a single transhepatic circulation in human subjects. Clin Res 7: 248 (Abstract)

34. Cherrington AD, Chiasson JL, Liljenquist JE, Jennings AS, Keller
U, Lacy WW (1976) The role of insulin and glucagon in the regulation of basal glucose production in the postabsorptive dog. $\mathrm{J}$ Clin Invest 58: 1407-1418

35. Robert JJ, Bier DM, Zhao XH, Mathews DE, Young VR (1982) Glucose and insulin effects on de novo amino acid synthesis in young men: studies with stable isotope labeled alanine, glycine, leucine and lysine. Metabolism 31: 1210-1218

36. Shulman GJ, Lacy WW, Liljenquist JE, Keller U, Williams PE (1980) Effect of glucose, independent of changes of insulin and glucagon secretion, on alanine metabolism in the conscious dog. $\mathrm{J}$ Clin Invest 65: 496-505

37. Wahren J, Felig P, Cerasi E, Luft R (1972) Splanchnic and peripheral glucose and amino acid metabolism in diabetes mellitus. $\mathrm{J}$ Clin Invest 51: 1870-1878

38. Chiasson JL, Cook J, Liljenquist JE, Lacy WW (1974) Glucagon stimulation of gluconeogenesis from alanine in the intact dog. Am J Physiol 227: 19-23

39. Garber AJ, Karl IE, Kipnis DM (1976) Alanine and glutamine synthesis and release from skeletal muscle. I. Glycolysis and amino acid release. $\mathbf{J}$ Biol Chem 251: 826-835

40. Garber AJ, Karl IE, Kipnis DM (1976) Alanine and glutamine synthesis and release from skeletal muscle. II. The precursor role of amino acids in alanine and glutamine synthesis. $J$ Biol Chem 251:836-843

41. Radziuk J, Inculet R (1983) The effects of ingested and intravenous glucose on forearm uptake of glucose and glucogenic substrate in normal man. Diabetes 32: 977-981

42. Albisser AM, Tiran J, Avruch LI (1981) Insulin dynamics with peripheral and portal infusions in pancreatectomized dogs. In: Cobelli C, Bergman RN (eds) Carbohydrate metabolism. Quantitative Physiology and Mathematical Modelling. John Wiley, Chichester, NY, Brisbane, Toronto, 297-313

43. Goldstein L, Newsholme EA (1976) The formation of alanine from amino acids in diaphragm muscle of the rat. Biochem $\mathbf{J} 154$ : $555-558$

44. Chiasson JL, Atkinson RLA, Cherrington AD, Keller U, SinclairSmith BC, Lacy WW, Liljenquist JE (1980) Effects of insulin at two dose levels on gluconeogenesis from alanine in fasting man. Metabolism 29: 810 818

45. Chiasson JL, Liljenquist JE, Finger FE, Lacy WW (1976) Differential sensitivity of glycogenolysis and gluconeogenesis to insulin infusions in dogs. Diabetes 25: 283-291

Received: 23 May 1984

and in revised form: 26. July 1985

Dr. Ernst-Joachim Freyse

Central Institute of Diabetes

DDR-2201 Karlsburg

GDR 